\title{
Renewable energy use and its policy in the United Kingdom
}

\section{英国再生可能エネルギー事情-利用の現状と政策一}

\author{
Fujio SUDA \\ The Energy Group, Department of Engineering, The University of Reading, Whiteknights, Reading RG6 \\ $6 A Y, U K$ (on leave from Department of Resources and Environment Science, School of Humanities and \\ Culture, Tokai University, 1117 Kitakaname, Hiratsuka 259-1292, Japan) \\ TEL:+44-118-931-8561 FAX:+44-118-931-3327 e-mail:F.Suda@reading.ac.uk
}

( Received 6, December 2001 Accepted 22, January 2002 )

\begin{abstract}
The purpose of this paper is to investigate the present status of energy use in the United Kingdom (UK) in comparison with that in Japan. A special attention was paid to the renewable energy use and its policy in order to meet the UK 10\% target of renewables electricity in 2010. There are some similarities and several differences in the energy use between the UK and Japan. One of the largest differences between them is the self sufficiency of energy: the UK is an export country of oil and gas in contrast to Japan (in which almost energy resources are imported). Energy consumption per capita is approximately equal with each other. Although the renewable energy use covers only a small fraction at present, policies on the renewable energy in the UK has undergone some drastic changes in a recent few years. Key policy instruments to meet the target are the Climate Change Levy and the Renewables Obligation. In relation to these policies greenness, renewability and sustainability were discussed.
\end{abstract}

Keywords: energy use in UK, renewable energy, Climate Change Levy, Renewables Obligation

\section{I.INTRODUCTION}

$\mathrm{BP}$ 統計によれば、1 2000 年の世界の 1 次エネルギー消 費量は、世界経済の引き続く強い成長と、寒い冬期気象パ夕 ーンへの逆戻りにより、リバウンドし 99 年より $2.1 \%$ 増加 した。これを燃料別に見ると、天然ガスと石炭は、1990-2000 年の年間平均以上の率で増加し、石油と原子力はそれらの 10 年平均並夕に増加した。水力の伸びはほんの少しであった。

一方、これを地域的に見ると、OECD 地域、特に北米に おいて増加が顕著であった。この年の 11 月と 12 月は過去 100 年間経験したことのないほどの寒さであったことによる。 USA とカナダのエネルギ一消費量を合計すると、世界の需 要の $28 \%$ 以上なるが、それが $2.6 \%$ も増加した（1990 年 から 2000 年の年平均増加率は $1.6 \%) 。 \mathrm{EU}$ における消費は 過去 10 年間の平均増加率 $1.1 \%$ より少し高い上昇率であっ た。一方、日本は低成長がすでに 5 年間も続いている。

世界の人口は 2001 年現在 61 億 3700 万人、 ${ }^{2}$ そして 2000 年に消費したエネルギーは 8752.4 MTOE(Million Tonnes of Oil Equivalent) ${ }^{1}$ であるから、世界の人々はひとり平均 1 年間に石油に換算して 1.43 トンのエネルギ一を使ったこと になる。世界には現在人口 3000 万人以上の国は 28 力国あ り、それらの国の人口の合計はほぼ 45 億人、すなわち世界
人口の4分の 3 になる。Figure 1 はこれら 28 力国の国ごと の一人当り 1 次エネルギ一消費量を石油換算卜ン(Tonnes of Oil Equivalent per Capita, TOE/Capita, $1 \mathrm{TOE}=10^{7}$ kilocalories)で表わし人口に対してプロットしたものである。 一つの国は一つの長方形で表わされ、長方形のたての長さが 一人当りエネルギー消費量を、横の長さが人口を表わしてい る。トップの USA から 28 位のバングラデシュまで大きい 方から順に並べてある。

一人当りエネルギ一消費量のランクがトップの USA と 2位のカナダが他の国から突出しているのがよく分かる（人 口 3000 万人以下の国まで含めると、トップは中東のカター ルで、何とUSAの4倍近い23.7 TOE/Capita となる)。USA では老人から子ども、赤ちゃんまで含めて 3 億人近い人たち が、石油に換算してひとり年間 8 トン以上のエネルギ一を消 費している。最低ランクのバングラデッシュは 0.096 TOE/Capita であり、世界平均の 15 分の 1、USA の実に 83 分の 1 と、地域、国によるエネルギ一消費量の格差が非 常に大きいことを示している。

日本と英国(UK) は共に先進国に位置付けられ、 OECD(Organization for Economic Co-operation and Development)の加盟国でもある。Figure 1 から明らかな 
ように、USA とカナダ以外の OECD 加盟国の一人当りエ ネルギ一消費量はほとんど3 4TOE/Capitaに集中してお り、日本は 4.02 で5位、UKは 3.77 で8位にランクされ 世界平均の 3 倍近く (それぞれ 2.8 倍、2.6 倍) である。

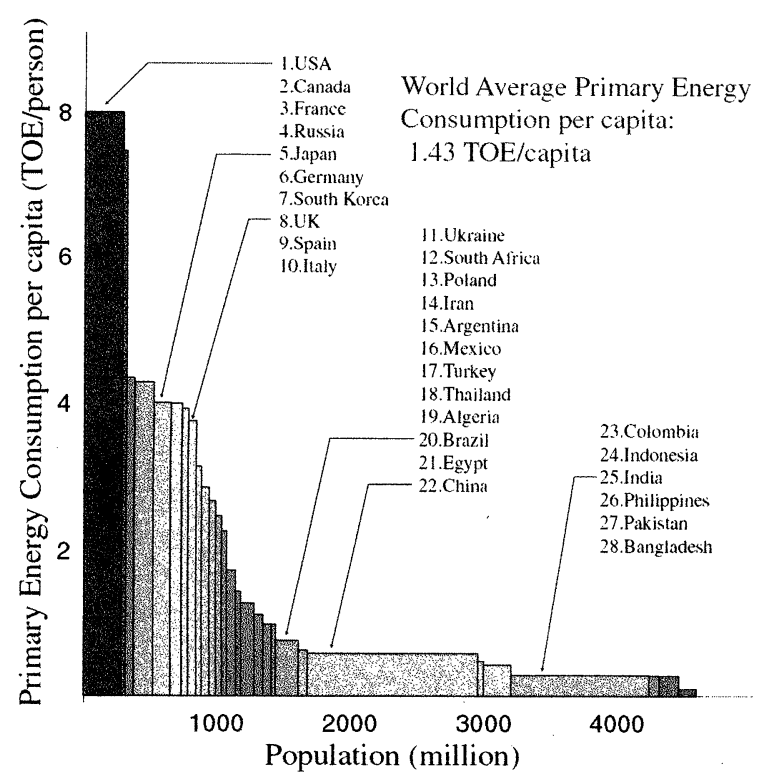

Fig. 1. Relation of population and primary energy consumption per capita by 28 countries which have more than 30 million population.

UK は日本と同様、北半球の中緯度に位置し、大陸と海 洋に挟まれた島国である。国土面積は日本のほぼ3分の2、 そこに日本の 2 分の 1 の数（世界人口の $1 \%$ ）の人々が暮ら している。一人当りのエネルギ一消費量がほぼ同じと言うこ とは、以下で示すように UK の全エネルギ一消費量が日本 の約半分であることを意味している。

UKはEU(European Union)の一員として、環境政策、 再生可能工ネルギ一利用をすすめている。英国政府は 2000 年の 2 月に 2003 年の終わりまでに電力の $5 \%$ 再生可能工 ネルギーでまかなうようにし、さらに 2010 年までにそれを 10\%にまで高めると言う目標を発表し、 ${ }^{3}$ その実現に向けて 2001 年の 4 月には気候変動税(CCL)か溌効し、また 2002 年 1 月には、再生可能（エネルギ一使用）義務 RO (the Renewables Obligation)が発効予定である。しかし、再生 可能エネルギ一利用の現状など、他の EU 諸国と比較する と決して進んでいるとは言えない。ハッキリ言えば、 $\mathrm{EU}$ 諸 国の中では最も遅れているように（筆者には）見える。しか し、この $2 、 3$ 年の UK の再生可能エネルギ一に対する対 忘は、日本の進むべき道を探る上で、お扑に参考になると 考える。以下では、まず歎国のエネルギ一の現状を日本と比 較する。続いて、再生可能エネルギ一に注目し、その現状、 およびそれらに対する政策などについて見て行くことにした い。

\section{COMPARISON OF ENERGY USE BETWEEN UK AND JAPAN}

Figure 2 に日本 (JPN) と英国 (UK) の1次エネルギ 一総供給量(Total Primary Energy Supply, TPES) の変遷 の様子を示す(data source: Energy Balances of OECD Countries 1998, 1999)。 ${ }^{4} 99$ 年の英国の TPES は 230 MTOE であり、一方、日本のそれは 515 MTOE 之英国の 2.2 倍以上である。しかし、68 年以前までは供給量は英国 の方が多かった。本は 60 年代から 70 年代にかけての高 度成長期に英国を一気に抜き去った。両国とも変化の様子は よく似ている。第1次、第2次エネルギ一色機の後の落ち込 みとその後の上昇、ここ数年の安定化の傾向もほぼ同じであ る。違いは変化の大きさである。定性的には同じでも、定量 的な差異のため、長い間に大きな差となってあらわれている。

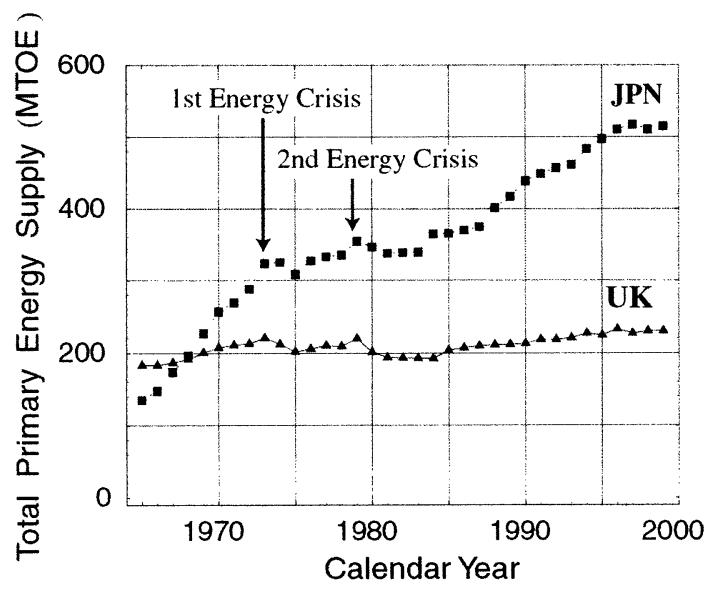

Fig. 2. Comparison of total primary energy supply (TPES) from 1965 to 1999 between the UK and Japan.

TPES の燃料別の比率も大きく変化してきた。試みに第 1 次工ネルギ一危機の年 $(73$ 年) と現在 (99 年) をくらべ てみると、この 27 年の間に英国の TPES が 221 MTOEか ら $230 \mathrm{MTOE}$ へ 4.1\%しか増加していないのに対し、日 本は324 MTOEから515 MTOEへと59\%も増加している。 各燃料ごとの変動には多くの共通点と少しの相違点が見られ る: 共通点を一言で言兄ば，非化石燃料の増大ということで ある。すなわち、

1. 石油の割合が減少 : 英国 $50.5 \% \rightarrow 36.2 \%$ 、日本 $77.8 \%$ $\rightarrow 51.7 \%$ 、

2. 天然ガス利用の増加 : 英国 $11: 4 \% \rightarrow 36.3 \%$, 日本 $1.6 \%$ $\rightarrow 12.1 \%$ 、

3. 原子力の増大: 英国 $3.4 \% \rightarrow 10.9 \%$, 日本 $0.8 \% \rightarrow 16.0 \%$ 。 一方、相違点としては石炭の比率の変動を挙げることができ る。すなわち、英国では 73 年には石炭の比率が $34.6 \%$ であ 
ったものが、 99 年には $15.4 \% に$ 半減したが、日本では $17.9 \%$ $\rightarrow 17.0 \%$ ほとんど変化していない（絶対値としては、2倍 以上になった)。

しかし、日英間のエネルギ一資源利用における最も大き な違い(筆者はこれこそ最も重要であると思えるのである が）は英国がエネルギ一資源（石油、天然ガス）の輸出国で あり、日本はそのほとんどを輸入に頼っているという事実に あると考える。99 年のUK のエネルギ一自給率は 1.23 、日 本のそれはなんと 0.20 である。 ${ }^{5}$ Figure 3 にエネルギー 量(石油換算卜ン、TOE)で見た英国の燃料の輸出入の変遷の 様子を示す (data source: Digest of UK Energy Statistics 2000)。 6 燃料の正味の輸出(net exports)を十で、正味の輸 入(net imports)を一で示してある。70 年代前半までの英国 の燃料輸入依存率は $50 \%$ を超えていた。しかし、1975 年に 北海油田の生産がスタートし、燃料貿易では 81 年に初めて 輸出超過となった。その後 89 92 にかけて一時的に小さな 輸入超過となるも、93 年以降輸出超過が続いている。(注 : 第1 次石油危機のすぐ後に石油生産が開始とはうらやましい 限りである)

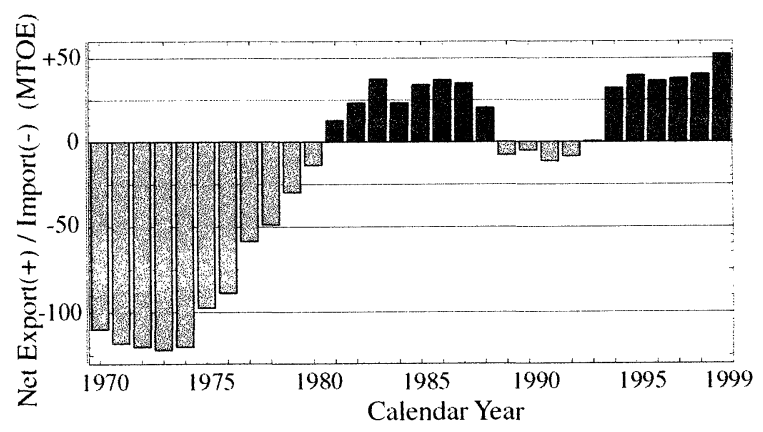

Fig. 3. UK net exports(+) and imports(-) of fuel from 1970 to 1999.

英国の 99 年の石油生産量は $150 \mathrm{MTOE}$ で、全エネルギ 一生産の $51 \%$ 、また天然ガスの生産量は 99 MTOE で 33\% を占め、いずれもこれまでで最大を記録している。7 99 年の 燃料の正味輸出は国内消費の $21 \%$ に相当する。(注 : それに しては、為替の関係かがリリンの值段はリッタ一当たり 2001 年 11 月現在 77 ペンスと日本より大分高い!)

続いて、第1次工ネルギ一危機当時(73 年)と現在(99 年) について、発電用燃料に注目して、そ㣗らの組み合わせの変 化を日・英で比較してみよう。Figures 4(a) (d)にそれらを パイチャートで表わしたものを示す(data source: Energy Balances of OECD Countries 1998, 1999)。 ${ }^{8}$ (a) と(b)は それぞれ英国(UK)の 73 年と 99 年の総発電量の燃料别割合 を、(c)と(d)はそれぞれ同じ年の日本(JPN)での割合を示し ている。この期間に発電量そのものは英国では2 $18 \mathrm{TWh}$ ら 363 TWh へと 1.67 倍に、日本では 465 TWh から 1056
TWh へと 2.27 倍になった。燃料の組み合わせを見ると、 73 年当時は両国とも 1 つの燃料に大きく依存していた（エネル ギ資源の片寄った使い方、バランスを欠いた使い方をして いた）ことが分かる。その一つの資源が英国では石炭であり、 日本においては石油であった。 ${ }^{*} 1999$ 年の両国の発電量の内 訳をみると((b),(d))、偏りがなくなりいくつかのほぼ同じ大 きさの領域に分離しているのが分かる。英国の場合には石炭、 天然ガス、原子力の 3 本柱によって支えら机、日本の場合に はそれらに石油火力による電力が加わって4本の柱で支光ら

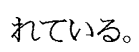

(a) U
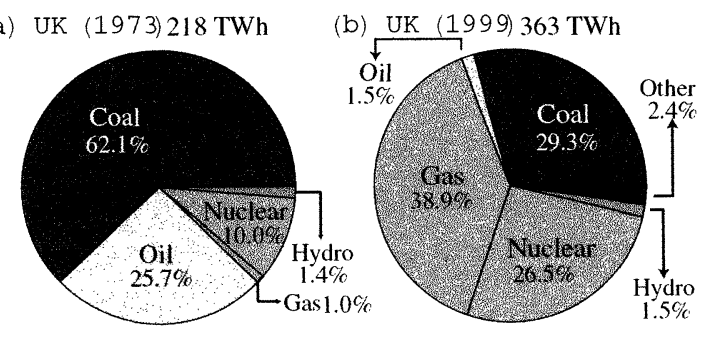

(c) JPN (1973) $465 \mathrm{TWh}$

(d) JPN (1999) $1056 \mathrm{TWh}$

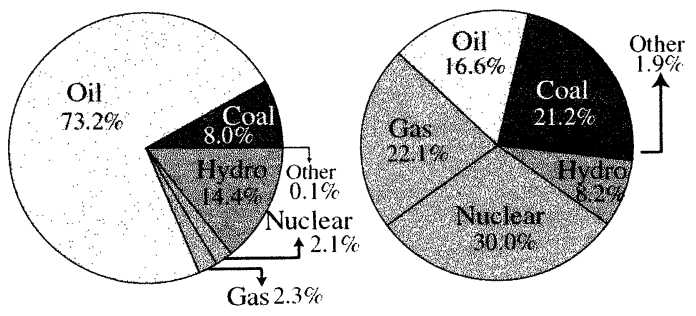

Fig. 4. Comparison of electricity generation by fuel between UK and Japan in 1973 and 1999.

日本に関してはエネルギ一危機後の電力源のベスト・ミ ックス化政策の結果と言えるだろう。一方、英国の場合には、 現状では天然ガス発電が $38.9 \%$ とトップであるが、天然ガ スが石炭火力を押さえてトップに立ったのは 99 年が初めて である。英国では石炭火力、石油火力発電のシエアが92 年 以降急激に減少し、それを補う形で天然ガスによる発電が大 きくのびた。つまり、英国はこの 10 年あまり天然ガスへの 転換をすすめ、結果として $\mathrm{CO}_{2}$ 放出量を大きく隇少させた （98 年の UK の温室効果ガス放出量は 90 年レベルに比較し

\footnotetext{
*この図(Fig.4)が出てきたついでに申し添えておくと、73年以前の 1960 年には日本の発電量の $50.65 \%$ ととの半分以上が水力による 電力であった。燃料の組み合わせはどんどん移り変わる。今後どの ような組夕合わせになっていくか、または組夕合わせにしていくか が現在問われている。電気と言う非常に使い勝手のよい2次エネル ギーを何からつくり出すかは、質のよい電気が安定的に供給されさ えすれば、利用者にはどうでもよいことなのかも知れない。しかし、 環境問題がそれを許さなくしつつある。つまり、利用者はその電気 がどのようにして作られたのかを知り、電力を選べる時代に突入し つつるのだ。後述するように、グリーン電力制度はこの方向への 第 1 歩と言える。
} 
て 8.5\%低い!)。日本においても石炭から天然ガスへの転 換が叫ばれているが、石炭火力による発電量はむしろ増加し ている。そ机は電力需要の増加をまかなうのに勢一杯のため である。

地球温暖化対策の一つとして温室効果ガスの放出を減ら すためには、再生可能工ネルギ一による発電を今後さらに増 やす必要があるのは明らかである。再生可能工ネルギ一発電 は Fig.4のパイチャートの中で Hydro と Other に含まれ る。総発電量に占める割合は廃棄物発電も入れて英国 3.8\%(dti: Digest of UK Energy Statistics 2000, p.169 で は $2.8 \%) 、 日$ 本 $10.0 \%$ とまだまだ少ないが、今後パイチャー トの中でこれらの面積をどのくらい広げることができるかが 環境問題を考光る際に重要である。以下では節を改めて英国 における再生可能エネルギ一利用とその政策に的を絞る。

\section{RENEWABLE ENERGY USE IN THE UK}

英国における再生可能エネルギ一全利用量の変遷を Fig. 5 に示す(data source: Digest of UK Energy Statistics 2000)。9 最近 7 年間て利用量は倍増し、99 年は $2912 \mathrm{kTOE}$ (UK の全1次エネルギーの 1.3\%) と 98 年にくらべて $9 \%$ 伸びた。バイオ燃料(biofuels)が圧倒的に多く、例えば 99 年で言えば全体の $81.1 \%$ がバイオ燃料である。続いて水力 が $15.9 \%$ 、風力 $2.6 \%$ 、ソーラー $0.34 \%$ 、地熱 $0.03 \%$ である

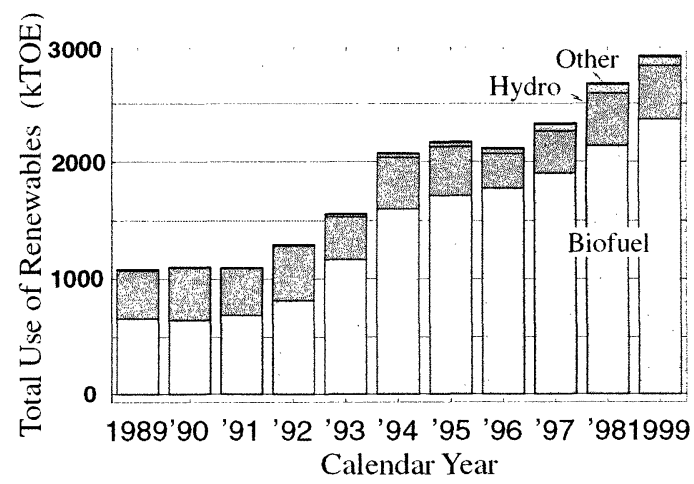

Fig. 5. Variation of total use of renewable sources in UK

再生可能然料(renewable fuels)は通常 11 のカテゴリー に分類される。そのうちバイオ燃料は Fig. 6 に示すように 6 種（その他を含め机ば7種）に分けられている（data source: Digest of UK Energy Statistics 2000)。10 また、 水力は発電容量 5 千キロワット( 1 万キロワットの場合もあ る）以上のものと以下のものに分けられ，それぞれ大規模水 力(large scale hydro)、小規模水力(small scale hydro) と呼 ばれる(この点については後に renewability と sustainability のところで議論する)。水力のほとんどは大 規模水力であり、小規模水力は全利用量の $0.7 \%$ に過ぎない。
再生可能エネルギ一は主に二つの形態で利用される。す なわち、電力利用と熱利用とである。1999 年に利用された 全再生可能エネルギー $2912 \mathrm{kTOE}$ の内、67.7\%に当たる $1971.5 \mathrm{kTOE}$ が電力として、残りの $32.3 \%$ の $940.5 \mathrm{kTOE}$ が熱として利用された。11 種の再生エネルギ一源について、 電力利用と熱利用の内訳を示したのが Fig. 7 である (data source: Digest of UK Energy Statistics 2000)。9 電力利 用の割合は 96 年の $55 \% 、 97$ 年の $60 \% 、 98$ 年の $65 \%$ と年々 増加している。 ${ }^{* *}$

\section{Total Renewable Energy Used in 1999 $=2.91$ MTOE}

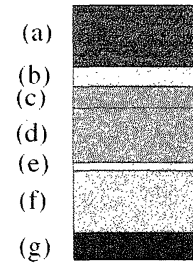

(a) Landfill gas $19.7 \%$

(b) Sewage gas $6.3 \%$

(c) Domestic wood $7.0 \%$

d) Industrial wood $17.4 \%$

(e) Straw combustion $2.5 \%$

(f) Refuse combustion 19

(g) Other biofuels $8.3 \%$

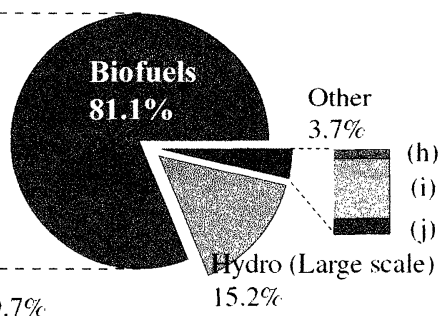

(h) Geothermal \& active sola heating $0.4 \%$

(i) Wind $2.6 \%$

(j) Small scale hydro $0.7 \%$
Fig. 6. UK renewable energy utilization in 1999.

Total Electricity Generation: 1971.5 kTOE Total Heat Generation: 940.5 kTOE

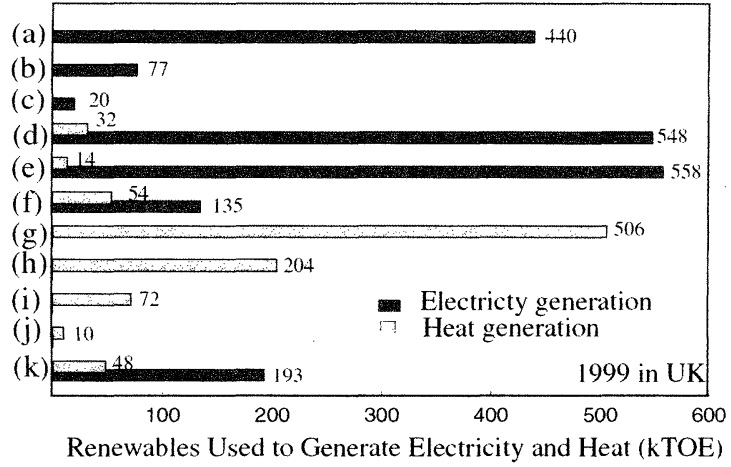

(a) Large scale hydro (b) Wind

(c) Small scale hydro (d) Waste combustion (e) Landfill gas

(f) Sewage sludge digestion (g) Industrial wood combustion (h)Domestic wood combustion (i) Straw combustion

(j) Active solar heating(2) (k) Other(1)

(1)Include farm waste digestion and combustion of poultry litter. waste tyres and industrial and hospital waste.

(2)Excludes all passive use of solar energy; includes geothermal.

Fig. 7. Renewable sources used to generate electricity and heat .

\footnotetext{
** Figure7 のように燃料の投入量(Inputs)で見ると廃棄物燃焼や、 工業用木材燃焼が水力より目立つて見える（大きい）が、結果とし て得られる電力量は水力の方か断然多いことに注意。これは水力(風 力も）の場合に戊入されたエネルギ一と結果として得られる電力 のエネルギーはほぼ等しいが、廃呆物発電のように一素をを介して 発電する場合に溔勢率を考慮する必要があり、エネルギ一投入量 と電力量の間には大きな差ができるからである。
} 


\section{POLICY ON RENEWABLE ENERGY IN THE UK}

ISES(International Solar Energy Society)の Official Magazine である RE-FOCUS の 2001 年 7、8 月号は、英 国の特集を組んでいるが、 ${ }^{11}$ その巻頭で Editor の Paul Spencer は「UK で再生可能エネルギ一技術が末だに盛り 上がらない理由の一つは、UKの再生可能エネルギ一政策が 未だに首尾一貫せず、焦点の定まった戦略にはなっていな い」からであると批判し、「UK は行政上の煩雑さの中で溺 れ死み危険の中にいる」と警告している。確かに、別の箇所 で David Elliot も指摘するように、UKK の徵税と控除、義 務と買い上げ、認可手続きと電力源の公表、取り引き可能な グリーン・クレジット、それに新電力取り引き協定などなど、 専門家でさえ途方に暮れている」感がある。

しかし、UK は現状ではまだ他の EU 諸国にくらべて RE(Renewable Energy)の比率は小さいかも知れないが、 10 年以上前から RE 促進のための布石は打ってきている。 すなおち、1989 年の電力法で (イングランドとウエールズ の）地域電力サプライヤ一に一定量の $\mathrm{RE}$ 電力を確保する様 要求できるようになった。これに従い、1990 年より第1次 非化石燃料使用義務 NFFO（the Non Fossil Fuel Obligations)-1 が開始され、98 年の第5次で終了するまで、 様々な契約がなされ実行に移されてきた。(NFFO は新規の 契約はないが、これまでの契約は有効であり、NFFO-3、4、 5 の契約のもとで 2000 年 6 月 30 日現在、331 プロジエク 卜、総容量 $834 \mathrm{MW}$ がコミッションされている)。NFFO により REのコストダウンがはかられ、初期の市場の創出に 成功したとの位置付けがなされている。12 (NFFO はイング ランドとウェールズでのみ有効であるが、スコットランド、 北アイルランドにもそれに対応した制度が作られている。）

NFFO は 1998 年て終了したが、英国における再生エネル ギ一政策の基礎を作ったと言える。

\section{IV-A. The climate change levy and the renewables obligation}

英国政府は 2000 年 2 月に温室効果ガス削減のための新 再生可能エネルギ一政策を発表し、国家目標として総電力に 占める $\mathrm{RE}$ 電力の比率を 2003 年までに $5 \%$ に そして徐々

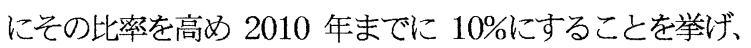
かつそれを消費者に受け入れ可能な価格て提供すると言うも のである。この国家目標幸成のための政策手段の二本柱が気 候変動税 CCL(the Climate Change Levy) と再生可能 (I ネルギ一使用）義務 RO(the Renewables Obligation)であ る。

（1）気候変動税 CCL(the Climate Change
Levy）:これは（電力とガスに対する）一種の工 ネルギー税のことで、(business energy usersす なわち、)工業、商業、および地方自治体などの公 共機関に対して課税される。税率は電力 0.43 pence/kWh で、電力価格の 7-15\%に相当する(ガ

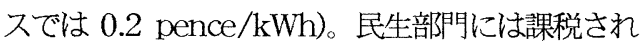
ない。2001 年 4 月に発効。これがどうして RE 促 進に役立つかと言うと、被課税者は彼等のエネル ギ一供給をグリーン・パワーに変更することによ り課税を免除されるからである。CCL 免除 $\mathrm{CCL}$ Exemption)のためには課税免除証書 (Levy Exemption Certificates)が必要である。

（2）再生可能（エネルギ一使用）義務 RO(the Renewables Obligation):ROは上述のNFFO にとって代わる制度として導入される。これによ り電カのサプライヤー (electricity suppliers) は 配電する電力の一部を再生可能源からの電力( $\mathrm{RE}$ 電力でまかなうことが要求され、それを購入しな ければならない。RO はイングランドとウェール ズのすべての認可電力サプライヤー(all licensed electricity suppliers)に適用される。この義務のレ ベルは徐々に高められ、最終的に 2010 年にはサ プライヤーは配電する電力の $10 \%$ RE 電力にし なければならない(現在は全電力販売の $2.8 \%$ RE 電力)。発効は早くて 2002 年 1 月 1 日。サプラ イヤーが RO に応ずる際にはいくつかのオプショ ンが用意されている。この時重要な役割をするの が OFGEM(the Office of Gas \& Electricity Markets)がジェネレー夕(the Generator)に対して 発行する再生可能（エネルギ一使用）義務証書 ROC(Renewables Obligation Certificates)であ る。詳細は省くがこの証書は電力市場で取り引き される。

CCLＲO の他にも RE 促進のための制度がある。例え ば、現時点ではコス卜的に他の電力源に太刀打ちできそうも ないが、将来必要になると考えられるREに対する資金援助 計画（Capital Grant）やRE に対するクオリティー認定計 画”Future Energy”がある。

ここまでは再生可能エネルギーRE(Renewable Energy) が具体的に何を指すのかハッキリ定義せずに使ってきた。し かし、例党ば 2010 年までに RE 電力を $10 \%$ に言った場合、 10\%に何を算入し、何を算入しないかハッキリ決めておかな いとあまり意味のある数字にならない。 Figure 7 で 11 種の 再生可能エネルギ一源を示したが、UK や EU の RE 政策 においてはこれらが全て常に含まれるわけではない。紛らわ 
Table 1. Clarification of what is included as renewable energy in UK and EU policy.

\begin{tabular}{|c|c|c|c|c|c|c|}
\hline Source & $\begin{array}{l}\text { UK } 10 \% \\
\text { national } \\
\text { target }\end{array}$ & $\begin{array}{l}\text { Renewables } \\
\text { Obligation } \\
\text { (Suppliers) }\end{array}$ & $\begin{array}{l}\text { CCL ex- } \\
\text { emption } \\
\text { (3) }\end{array}$ & $\begin{array}{l}\text { Capital } \\
\text { Grantts } \\
\text { (4) }\end{array}$ & $\begin{array}{l}\text { Future Energy } \\
\text { (sources sold } \\
\text { as GE (5)) }\end{array}$ & \begin{tabular}{|l|} 
EU \\
Renewables \\
Directive \\
\end{tabular} \\
\hline Landfill gas & 0 & 0 & 0 & $x$ & 0 & 0 \\
\hline Sewage gas & 0 & 0 & 0 & $x$ & 0 & 0 \\
\hline \begin{tabular}{|l|}
$\begin{array}{l}\text { Energy from } \\
\text { waste (1) }\end{array}$ \\
\end{tabular} & 0 & $x$ & 0 & $x$ & 0 & in discussion \\
\hline Hydro $>10 \mathrm{MW}$ & 0 & $x$ & $x$ & $x$ & $50 \%$ of UK capacity & in discussion \\
\hline Hydro $<10 \mathrm{MW}$ & 0 & 0 & 0 & $x$ & 0 & 0 \\
\hline Onshore wind & 0 & 0 & 0 & $x$ & 0 & 0 \\
\hline Offshore wind & 0 & 0 & 0 & 0 & 0 & 0 \\
\hline $\begin{array}{l}\text { Agricultural and } \\
\text { forestry residues }\end{array}$ & 0 & 0 & $\mathrm{O}$ & $x$ & 0 & $\mathrm{O}$ \\
\hline \begin{tabular}{|l|} 
Energy Crops \\
\end{tabular} & 0 & 0 & 0 & $\mathrm{O}$ & $\mathrm{O}$ & 0 \\
\hline Wave power & 0 & 0 & 0 & $x$ & 0 & 0 \\
\hline Photovoltaics & 0 & 0 & 0 & $x$ & 0 & 0 \\
\hline Solar thermal (2) & $x$ & $x$ & $x$ & $x$ & $x$ & 0 \\
\hline
\end{tabular}

(1) Energy recovery from municipal solid waste and from mixed streams of industrial and commercial waste

(2) Solar thermal is not included in the DTI (Department of Trade \& Industry) official document, status of this in the UK unclear, does count at the EU level.

(3) CCL: Climate Change Levy.

(4) Capital grants are subsidies to renewable energy technologies that are considered to be non-commercial. Although only off-shore wind and energy crops are mentioned here, the recent environment speech by Blair promised money to other technologies as well including photovoltaics and wave power.

(5) GE: Green Electricity.

しいが政策ごとに異なるのである。未だはっきりせずに議論 中のものもある。Table 1 に各種の RE 政策とそれにに含まれ る RE 源を示した。 ${ }^{13,14}$ Capital Grants の対象は沖合い風 力発電とエネルギー作物の二つだけである。ちょつと気にな るのは $\mathrm{RO}$ から大規模水力発電と廃萧物発電が拢けている こと、および太陽熱がほとんどの政策て対象外になっている ことである。

\section{IV-B. Green electricity}

UK の電力産業はジェネレー夕(Generator)、トランスミ ッター(Transmitter)、ディストリビュータ(Distributor)、 サプライヤー(Supplier)に分れており、再生可能発電プラン トの電力は一般に配電網(distribution grid)に連結されてい る。 ${ }^{15} 99$ 年 5 月に英国の電力市場か浣全に自由化されて以 来、顧客はサプライヤーの提供するグリーン電力料金制 (green electricity tariffs)に登録することができるようにな った。現在市場に出回っているグリーン電力はグリーン・ソ 一ス(green source)とグリーン・ファンド(green funds)の 二種に分けられる。グリーン・ソースの顧客は市場で売買さ れる再生可能電力をサプライヤーから購入する。また、グリ ーン・ファンドの顧客は新たな再生可能発電プラント建設の ための基金に資金を提供する。

グリーン電力料金制を提供している電力サプライヤーは、 全部で 14 社ありそのうちの 8 社はグリーン・ソースを、 4 社はグリーン・ファンドを、そして 2 社は両方提供している。 3 社をを除くすべてのサプライヤーは民生部門の顧客にもグ
リーン電力を販売している。2001 年 10 月現在、UK のグ リーン・エネルギ一顧客数は 27,000 件で、大多数は民生部 門が占める。非民生部門の顧客は政府、民間企業、NGO な ど百数十件程度である。民生部門のグリーン・エネルギ一消 費量は 87 GWh、非民生部門は 384 GWh である。グリー ン電力のトップ・ユーザーはProctor and Gamble UK で、 ロンドン電力会社からグリーン電力料金制で年間 $121 \mathrm{GWh}$ を購入している。ちなみに、2000 年の英国における総グリ 一ン電力販売量の $19 \%$ 年水力によるものである。1 16

Table 2. Green energy market in the UK and Europe.

\begin{tabular}{|c|c|c|}
\hline & UK & Europe \\
\hline Population & $\begin{array}{l}59,647,790 \\
\text { (July 2001) }\end{array}$ & $\begin{array}{c}377,614,000 \\
(2001)\end{array}$ \\
\hline $\begin{array}{l}\text { Green energy } \\
\text { customers }\end{array}$ & 27,000 (Oct.2001) & $\begin{array}{l}950,000 \\
\text { (July 2001) }\end{array}$ \\
\hline $\begin{array}{l}\text { Share of } \\
\text { renewable energy }\end{array}$ & $2.8 \%(1999)$ & $6 \%(1999)$ \\
\hline Target & $10 \%$ in 2010 & $12 \%$ in 2010 \\
\hline
\end{tabular}

(data source: http://www.greenprices.com)

これらをヨーロッパ全体と比較してみると(Table 2)、ヨ 一ロッパ全体の総発電量に占める $\mathrm{RE}$ 電力の割合が $6 \%$ であ るのに対して、UK はその半分以下の $2.8 \%$ に過ぎない。さ らに、グリーン・エネルギー顧客件数はヨーロッパ全体では 95 万件 $(2001$ 年 7 月現在) に対し、UKは前述したように 27,000 件である。人口はヨーロッパ全体の $15.8 \%$ であるの に対し、グリーン・エネルギ一顧客件数は $2.8 \%$ に過ぎない。 
これを見ても UK はヨーロッパ全体の中でもグリーン・エ ネルギ一の普及は遅れていると言わざるを得ない。

\section{V . GREENNESS, RENEWABILITY AND SUSTAINABILITY}

人間的尺度で見て永遠に続く自然界の工ネルギ一の流れ を利用して取り出されたエネルギーが再生可能エネルギー (Renewable energy)であり、それはまた非化石・非核工ネ ルギ一源でもある。また、ある再生可能工ネルギ一源が従来 のエネルギー・システムに比べて環境的、社会経済的により すぐれたものである時、それは持続可能エネルギー (Sustainable energy)と夕なされる。つまり再生可能エネル ギ一を社会・経済的、環境的フィル夕一を通して篩にかけた ものガ持続可能工ネルギ一であり、二つは異なる概念と見る のが妥当である。

このことを水力を例に考えてみると、水力は落下あるい は流れる水のもつエネルギーのことで一般にタービンにより パワーを取り出す。人間的な尺度で見れば永遠に続く地球の 水循環の一部を利用しているのであるから、従って水力は再 生可能工ネルギーの一つである。さらにそれは非化石・非核 エネルギーで、かつその生産 (発電) には事実上 $\mathrm{CO}_{2}$ を放 出しない。

それでは水力によるパワーは全て持続可能エネルギーと してかまわないだろうか?水力パワ一の生産にダムを作って 水を溜めるような場合、沈殿物の分解によるメタン発生や、 流水系の変更による生態系への影響などの環境インパクトが 予想される。規模が大きい程そのインパクトは大きいであろ う。つまり水力生産の規模により、ぞこかに線引きをして、 それ以下なら水力による電力は持続可能工ネルギ，すなお ちグリーン・エネルギーであり、以上ならそうではないと分 けて考劣る必要があることを意味する。このようにして、ド イツのグリューナー・ストローム・ラベル、カナディアン・ エコロゴは発電設備容量の大小による基淮を採用した。また スウェーデンフィンランド、ノルウェーのエコラベリング・ スキームでは、設備の設置年代を基淮にし、あるいは環境イ ンパクトに関するアセスメントを行って総合的に判断するス イスの Naturmade などもある。ちなみに再生可能源に関 するヨーロッパ委員会は、従来型水力と持続可能水力の境界 を発電容量 1 万 $\mathrm{kW}$ と決めた。16***

ヨーロッパでは、スウェーデン、スイス、ノルウェーな どは水力発電の割合が非常に大きく(ノルウェ一は全発電量

\footnotetext{
**境界をどこに設けるかなどどうでもよいように見えるが、実際 上グリーン電力取り引きや、 $\mathrm{CO}_{2}$ 削減量の計算 $\mathrm{CCL}$ 課税などの 際に直接関わってくる問題である。ヨーロッパだけでなく世界的な 基㔼を設けるべきであろう。
}

の 99.5\%)、水力は付加的な支援を必要としない従来型の、 コスト的にも有利な発電方法と見ることができるが、国家間 での電力取り引き、特にグリーン電力市場においてはグリー ン電力のラベリングに関する基淮は重要である。1999にド イツのグリーン電力ヨーロッパ市場で取り引きされた電力の 28\%が水力による電力であった。

\section{VI.CONCLUSIONS}

こうして見ると、英国の再生可能エネルギ一政策はこの 1、2 年目まぐるしい変化を見せたと言える。そしてその変 化はヨーロッパ各国と足並みをそろえる形て現在も続いてい る。N節の最初のところで紹介した RE-FOCUS の Paul Spencer の批判については、日本から見るとそれほど悲観 的になる必要はないように見える。また、気候変動朹組及条 約の $\mathrm{CO}_{2}$ 削減についても UK にとつてはそれはど無理な数 值ではなく、十分達成可能なものである。ピークは過ぎたと いわれながら、UKは石油、天然ガスの輸出国である。エネ ルギ一資源、そしてRE利用を日本と比較する際にもその根 底にはこの違いからくる余裕を感ぜざるを得ない。

日本ではグリーン電力制度がスタートしたばかりで、こ の(20001年の) 9 月に企業向けのグリーン電力証書システ ムの運用第 1 号が出たばかりである。この制度は「我が国で 初めての壮大な社会実験」と位置付けられている。 ${ }^{17}$ 日本 のグリーン電力システムが「民間企業による自発的な自然工 ネルギー普及への取り組み」 ${ }^{17}$ であるのに対し、UK のそれ はすべての電力サプライヤーに対して義務付けられる法的強 制力をもつ制度であるところに違いがある。日本は電力の自 由化に向けてやっと動き出したところであり、気候変動枠組 み条約の批准に向けてこれから対策を立てねばならない時て ある。 RE の導入数値自体で比較すれば日本はUKよりも大 きいかも知れないが、将来を見据えた政策面においてはUK は EU 諸国と共に日本より整備され、進んでいる。今後日 本における RE 政策を考える上で多いに参考になると思う。 ただし、各国、各機関でまちまちのグリーン電力のラベリン グに関しては、早急に統一する必要があるであろう。

\section{ACKNOWLEDGEMENT}

本稿執筆に当たり、資料収集に御協力いただき、また有 益なアドバイスをいただいたレディング大学エネルギーグル 一プの Dr. J. D. Burton、およびProf. P. D. Dunn に心よ り感謝します。

\section{REFERENCES}

${ }^{1}$ BP. BP Statistical Review of World Energy 2001.

${ }^{2}$ Population Reference Bureau: 2001 World Population Data Sheet. 
${ }^{3}$ dti (Department of Trade and Industry): New and Renewable Energy-Prospects for the $21^{\star}$ Century-, The Renewable Obligation Preliminary Consultation, October 2000, p.5.

${ }^{4}$ IEA(International Energy Agency): Energy Balances of $O E C D$ Countries 1998, 1999 , pp. II.132-137 and pp. II.216-221 (Paris, 2001).

${ }^{5}$ ibid. p.II.323

${ }^{6} \mathrm{dti}$ (Department of Trade and Industry): Digest of United Kingdom Energy Statistics 2000, Production Editor. Mari Scullion, (A National Statistics Publication, London, 2000) p.38.

${ }^{7} \mathrm{dti}$ (Department of Trade and Industry): UK Energy in Brief, July 2000 , p.7.

${ }^{8}$ IEA (International Energy Agency): Energy Balances of OECD Countries 1998, 1999 , pp. II.268-281 (Paris, 2001).

${ }^{9} \mathrm{dti}$ (Department of Trade and Industry): Digest of United Kingdom Energy Statistics 2000, Production Editor. Mari Scullion, (A National Statistics Publication, London, 2000) p.168, 185.

${ }^{10}$ ibit. p. 167.
${ }^{11}$ ISES (International Solar Energy Society): RE-FOCUS, July/August 2001, p3.

${ }^{12} \mathrm{dti}$ (Department of Trade and Industry): New and Renewable Energy-Prospects for the $21^{*}$ Century-, The Renewable Obligation Preliminary Consultation, October 2000, p.10.

${ }^{13}$ JudithLip: RE-FOCUS, July/August 2001, pp.10-12.

${ }^{14} \mathrm{dti}$ (Department of Trade and Industry): New and Renewable Energy-Prospects for the $21^{\star}$ Century-, The Renewable Obligation Preliminary Consultation, October 2000, p.17.

${ }^{15}$ C. Mitchell: Neutral Regulation-The Vital Ingredient for a Sustainable Energy Future, Energy \& Environment, 11[4]377-389 (2000).

${ }^{16}$ RE-FOCUS, July/August 2001, p.46, 47.

${ }^{17}$ T. Takao: The Role of Green Electricity and Prospects in Japan, Energy Resources 22[4] 1-6(2001) (in Japanese). 